\title{
Class Ila bacteriocin resistance in Enterococcus faecalis V583: The mannose PTS operon mediates global transcriptional responses
}

\author{
Mona Opsata ${ }^{1 *}$, Ingolf F Nes', Helge Holo ${ }^{1,2}$
}

\begin{abstract}
Background: The class lla bacteriocin, pediocin PA-1, has clear potential as food preservative and in the medical field to be used against Gram negative pathogen species as Enterococcus faecalis and Listeria monocytogenes. Resistance towards class lla bacteriocins appear in laboratory and characterization of these phenotypes is important for their application. To gain insight into bacteriocin resistance we studied mutants of E. faecalis V583 resistant to pediocin PA-1 by use of transcriptomic analyses.

Results: Mutants of E. faecalis V583 resistant to pediocin PA-1 were isolated, and their gene expression profiles were analyzed and compared to the wild type using whole-genome microarray. Significantly altered transcription was detected from about 200 genes; most of them encoding proteins involved in energy metabolism and transport. Glycolytic genes were down-regulated in the mutants, but most of the genes showing differential expression were up-regulated. The data indicate that the mutants were relieved from glucose repression and putative catabolic responsive elements (cre) could be identified in the upstream regions of $70 \%$ of the differentially expressed genes. Bacteriocin resistance was caused by reduced expression of the mpt operon encoding the mannose-specific phosphoenolpyruvate:carbohydrate phosphotransferase system (PTS), and the same transcriptional changes were seen in a mptD-inactivated mutant. This mutant also had decreased transcription of the whole mpt operon, showing that the PTS is involved in its own transcriptional regulation.

Conclusion: Our data confirm the important role of mannose PTS in class lla bacteriocin sensitivity and we demonstrate its importance involving global carbon catabolite control.
\end{abstract}

\section{Background}

Bacteriocins are bacterial peptides or proteins inhibitory to bacteria closely related to the producer. Many of the bacteriocins produced by lactic acid bacteria (LAB) have inhibitory spectra spanning beyond the genus level and have a potential in defending unwanted microflora. Since they are produced by food grade bacteria, some are being used in food preservation. However, LAB bacteriocins could have a potential in the medical field. With the increasing spread of antibiotic resistance, the need for alternative antimicrobials is growing. Most of the bacteriocins of LAB are small, heat-stable, cationic

\footnotetext{
* Correspondence: mona.opsata@umb.no

'Laboratory of Microbial Gene Technology and Food Microbiology, Department of Chemistry, Biotechnology and Food Science, Norwegian University of Life Sciences, N-1432 Ås, Norway

Full list of author information is available at the end of the article
}

peptides and are divided into two classes; class I, the lantibiotics containing modified amino acids and class II, the non-lantibiotics having regular amino acid residues [1]. Among the regular peptide bacteriocins, those belonging to class IIa are produced by a large number of LAB and are best studied [2]. These bacteriocins have highly conserved amino acid sequences, and have a largely common inhibitory spectrum which includes pathogens like Listeria monocytogenes and Enterococcus spp. Their mode of action is different from common antibiotics $[3,4]$. Bacterial resistance towards these bacteriocins does not appear to be common in nature [5], while in laboratory experiments resistance to some bacteriocins appear at high frequency [6,7]. Characterization of the resistant phenotype is important for assessment of the usefulness for application of bacteriocins. The target for class IIa bacteriocins is the mannose phosphotransferase 
system (mpt-PTS) [8-11], and mutants lacking a bacteriocin dedicated target are insensitive to the bacteriocin. This mannose PTS is the major uptake system for mannose and glucose in the bacteria [12]. PTS components are also involved in gene regulation of catabolic operons [13]. Hence bacteriocin resistance is likely to cause multiple effects. Among the effects seen in class IIa bacteriocin resistant strains of $L$. monocytogenes are changes in cell envelope, alterations in fatty acid composition [14-17], and a metabolic shift [18]. Enterococci are among the most common LAB habitants in the mammalian microflora, and they are commonly found in fermented foods where they contribute to flavour and preservation, but enterococci have also become the most frequent antibiotic-resistant bacteria in hospitals causing serious infections. As such strains could potentially be defeated by using bacteriocins we need more knowledge about bacteriocin resistance phenomena in enterococci. In this work we have performed transcriptional analyses by genomic microarray to study the effects on class IIa bacteriocin resistance in E. faecalis V583, a vancomycin-resistant clinical isolate $[19,20]$. Our data confirm the important role of the mannose PTS in bacteriocin sensitivity and provide new insight into its role in global gene regulation in this organism.

\section{Methods}

\section{Bacterial strains and growth conditions}

Enterococci were routinely grown at $37^{\circ} \mathrm{C}$ in $\mathrm{M} 17$ (Oxoid) supplemented with $0.5 \%$ glucose (GM17) or brain heart infusion (BHI) (Bacto ${ }^{\text {Tix }}$ BHI, Difco Laboratories, Becton, Dickinson and Company). Growth was monitored using a Bioscreen $\mathrm{C}$ instrument (Oy Growth Curves $\mathrm{Ab} \mathrm{Ltd}$.), at $37^{\circ} \mathrm{C}$.

\section{Bacteriocin assay}

Pediocin PA-1 was obtained from Pediococcus acidilactici Pac 1.0 [21] grown for 24 hours in MRS (Oxoid) at $30^{\circ} \mathrm{C}$. The culture supernatant was heated to $70^{\circ} \mathrm{C}$ for $15 \mathrm{~min}$, and applied to a column of SP-sepharose (Amersham Pharmacia Biotech). The column was washed with sodium phosphate buffer (10 mM, pH 5) before the concentrated bacteriocin was eluted with 1 $\mathrm{M} \mathrm{NaCl}$. Bacteriocin activity was measured with a 96well microtiter-plate assay [22]. Stationary phase cultures diluted 100 times in MRS were used as indicators. The plates were incubated for 16 hours at $37^{\circ} \mathrm{C}$, and growth was measured spectrophotometrically at $620 \mathrm{~nm}$. One bacteriocin unit (BU) was defined as the amount of bacteriocin that inhibited growth of the indicator strain E. faecalis V583 by $50 \%$ under these conditions.

\section{Isolation of resistant mutants}

Aliquots from a culture of E. faecalis V583 grown in GM17 to an optical density at $600 \mathrm{~nm}$ of 1.0 were spread onto GM17 agar plates containing $10 \mathrm{BU} / \mathrm{ml}$ pediocin PA-1. After incubation overnight at $37^{\circ} \mathrm{C}$, the spontaneously pediocin PA-1 resistant mutant MOP1 was picked. Mutant MOP5 was obtained by inoculating MOP1 in lactic broth [23] supplemented with $800 \mathrm{BU} /$ $\mathrm{ml}$ pediocin PA-1. After growth over night the mutant was colony purified on GM17 agar. Mutant MOP2 was resistant to 2-deoxyglucose (2-DG), 2-DG is known to enter the bacteria via mannose PTS [24]. One $\mu \mathrm{l}$ of an E. faecalis culture grown overnight at $37^{\circ} \mathrm{C}$ in $\mathrm{M} 17$ broth supplemented with $0.2 \%$ fructose was spread onto M17 agar (Oxoid) plates containing $10 \mathrm{mM}$ 2-DG (Sigma) and $0.2 \%$ fructose. After incubation for 24 hours, the mutant was isolated. To construct a strain with an inactivated $m p t$, a 355 basepair fragment of gene $m p t D$ was PCR amplified using primers mptDi-F and mptDi-R and the template was DNA from V583 (Table 1). The fragment was ligated into the SnaB1 site in pAS222 [25]. Transformation established the recombination plasmid pGhost $\Delta m p t D$ in Escherichia coli EPI300. The resulting plasmid was isolated and electrotransformed into E. faecalis V583 as described by Holo and Nes [26]. Transformants were grown at $28^{\circ} \mathrm{C}$. Integration into the V583 genome was achieved by growth at $37^{\circ} \mathrm{C}$ in the presence of tetracycline as described previously [25]. Integration of the plasmid into mptD was verified in mutant MOM1 by DNA sequencing using primers mptD-F and mptD-R.

\section{Metabolites}

Glucose, and metabolic products were analyzed by highperformance liquid chromatography and headspace gas chromatography $[27,28]$.

\section{Acid production}

Cells were grown in BHI to OD $=0.2$, harvested by centrifugation, then washed and resuspended to the same cell density in $5 \mathrm{mM}$ sodium phosphate buffer pH 6.9 containing $0.025 \%$ bromocresol purple. Acidification was monitored at $37^{\circ} \mathrm{C}$ in $200 \mu \mathrm{l}$ reaction volumes in microtiter plates using a microtiter reader recording absorbance at $620 \mathrm{~nm}$ after the addition of either glucose or glycerol (1\%).

\section{RNA isolation, CDNA synthesis and microarray experiments}

Cultures of strain V583 and its mutants grown overnight in (BHI) (Bacto ${ }^{\text {Tw }}$ BHI, Difco Laboratories, Becton, Dickinson and Company) were diluted 1:50 in BHI and incubated further. Bacterial cells were harvested at OD 
Table 1 Plasmids, bacterial strains and primers used in this study

\begin{tabular}{|c|c|c|}
\hline & Description, characteristics ${ }^{\mathrm{a}}$ or sequence $\left(5^{\prime} \rightarrow 3^{\prime}\right)$ forward primer, reverse primer & Source or reference \\
\hline \multicolumn{3}{|l|}{ Plasmid } \\
\hline pAS222 & Shuttle vector, TetR & [25] \\
\hline pGhost $\triangle m p D$ & Insertion inactivation vector of $m p t D$ & This work \\
\hline \multicolumn{3}{|l|}{ Strain } \\
\hline E. coli EPI300 & & Epicentre Technologies, USA \\
\hline E. faecalis V583 & Wild type & [20] \\
\hline MOP1 & Resistant mutant, from exposure to pediocin PA-1 $10 \mathrm{BU} / \mathrm{ml}$ & This work \\
\hline MOP2 & Resistant mutant, from exposure to $10 \mathrm{mM}$ 2-deoxsyglucose & This work \\
\hline$\overline{M O P 5}$ & Resistant mutant, from exposure to pediocin PA-1 $640 \mathrm{BU} / \mathrm{ml}$ & This work \\
\hline MOM1 & Inserted inactivated $\mathrm{mptD}$ & This work \\
\hline Pediococcus acidilactici Pac 1.0 & Pedioicn PA-1 producer & [21] \\
\hline Primer & & Target DNA \\
\hline $\operatorname{arcA-F}$ & TAACTCGACAACGGGAAACC & EF0104, $\operatorname{arcA}$ \\
\hline $\operatorname{arcA-R}$ & TCCCAATGGCCACTACTTCT & EF0104, $\operatorname{arcA}$ \\
\hline citE-F & CGGTGATTAACCCTCGTCAA & EF3320, citE \\
\hline citE-R & ACGGAGATAACACCGGAACC & EF3320, citE \\
\hline dnaB-F & TAGAAATGGGGGCAGAATCA & EF0013, dnaB \\
\hline dnaB-R & ATTCGCACGGGACAAACTAC & $\mathrm{EF} 0013$, dnaB \\
\hline mptAB-F & TGACCTATGGGGAGGAACAC & EF0020, mptAB \\
\hline mptAB-R & GTCGCAATTTCTTGTGCTGA & $\mathrm{EF} 0020, m p t A B$ \\
\hline $\mathrm{mptC-F}$ & ATTCGTATTGCGATTCCAGCA & EF0021, mptC \\
\hline $\mathrm{mptC}-\mathrm{R}$ & TGCATAACCTACGGCAACGAC & EF0021, mptC \\
\hline mptD-F & TCGTTGGTCATTCATGTGGT & EF0022, mptD \\
\hline mptD-R & GTTGAACTAATGCGGCCAGT & EF0022, mptD \\
\hline mptDi-F & GAAGGAGGAGCAAAGAAAATGGCA & EF0022, mptD \\
\hline mptDi-R & CACCGACACCGGCTAAAGGAC & EF0022, mptD \\
\hline mptO-F & TATCCAAATTCCGTGGGAAG & EF0024, manO \\
\hline mptO-R & TAACACTCGCTTCGGCTCTT & EF0024, manO \\
\hline pgk-F & AATGACGCTCCTITCCACAC & EF1963, pgk \\
\hline pgk-R & TTCAAATACGCCCATTGGT & EF1963, pgk \\
\hline
\end{tabular}

${ }^{\mathrm{a}} \mathrm{Tet} R$, tetracycline resistance

$600 \mathrm{~nm} 0.2$ by centrifugation, washed in TE-buffer (10 mM Tris-HCl, $1 \mathrm{mM}$ EDTA pH 7.4), and quickly frozen in liquid nitrogen. From the frozen bacteria pellets $\left(-80^{\circ} \mathrm{C}\right)$ lysate was obtained after lysozyme digestion $(10 \mu \mathrm{g} / \mathrm{ml})$ and total RNA was extracted using the RNeasy Mini kit (Qiagen) according to the manufacturer's protocol. Residual DNA was removed on-column with RNase free DNase (Qiagen) (27 Kunitz units). The integrity of RNA samples was verified using capillary electrophoresis on prokaryotic total RNA Nano LabChip with Bioanalyzer 2100 (Agilent Technologies), and purity and concentration were determined by optical density measurements with NanoDrop ND-1000 (NanoDrop Technologies, Inc.). Synthesis of cDNA and incorporation of aminoallyl-labeled dUTP (Sigma) were performed at $42^{\circ} \mathrm{C}$ for 3 hours with Superscript III
(Invitrogen) after preheating $10 \mu \mathrm{g}$ of total RNA with $30 \mu \mathrm{g}$ random hexamers as specified by Aakra et al. [29]. RNA in the cDNA samples was hydrolyzed and then the reactions were neutralized [29]. The cDNA was purified by washing through MinElute columns (Qiagen) and dried in a vacuum centrifuge. Coupling of the aminoallyl-labelled cDNAs to the fluorescent $N$-hydroxysuccinimide-ester dyes; cyanine- 3 and cyanine- 5 (in DMSO) (Amersham Pharmacia) were done for $30 \mathrm{~min}$ in $18 \mu \mathrm{l}$ $50 \mathrm{mM} \mathrm{Na} \mathrm{CO}_{3}$ buffer $\mathrm{pH}$ 9.3. The probe was purified through MinElute columns and dried. Corresponding probes generated from the wild type and the mutant samples were combined, then prehybridisation, hybridisation, washing and drying were performed as described [29]. Scanning of hybridized microarray slides were done with Agilent G2505B scanner (Agilent 
Technologies). Transcriptome analyses were performed using whole-genome DNA microarray of the E. faecalis V583 genome containing PCR fragments representing $94.7 \%$ or 3160 of all open reading fragments in five copies on each slides [29].

\section{Data analysis}

The microarray images were analyzed using GenePix Pro 6.0 software (Axon), and raw data from each slide was preprocessed independently. The images were gridded to locate the spots corresponding to each gene. Fluorescence intensities for mean spot signal to median background from both channels $(532 \mathrm{~nm}, \mathrm{Cy} 3$ and $635 \mathrm{~nm}$, Cy5) were extracted for data analysis and normalization. Spots with diameter $<60$ micrometer and spots of low quality were filtered. All filtering and Lowess normalization were performed in BASE (BioArray Software Environment) [30]. Average log2-transformed intensity Cy3/ Cy5 ratio for each gene in 5 replicates on each array was calculated. Statistical analyses using SAM (Significance Analysis of Microarrays) were performed on the normalized microarray data to identify significant differentially expressed genes in each of the individual mutants by one-class analyses [31]. SAM was used with a stringent confidence level by setting the false discovery rate, FDR, to zero, meaning no genes were identified by chance. The microarray data obtained in this study has been deposited in the ArrayExpress database (http://www.ebi.ac.uk/ arrayexpress/) with accession number E-TABM-934.

\section{Quantitative real-time PCR (qPCR)}

RNA was isolated independently from that used for transcriptome analysis. Synthesis of cDNA were performed from 150 ng of total RNA confirmed free of DNA after an additional DNase treatment, $6 \mu \mathrm{g}$ hexamers, $10 \mathrm{mM}$ of dNTP with Superscript III and supplied reagents as described above. The primers used in real-time quantitative PCR are listed in Table 1. Real-time PCR was performed with a cDNA dilution in triplicates, representing 0.75 ng RNA, $0.1 \mu \mathrm{M}$ of each primer with FastStart SYBR Green master included ROX (Roche Applied Science) on an ABI Prism 7700 Sequence Detection System (Applied Biosystems). After denaturation at $95^{\circ} \mathrm{C}$ the program was 40 cycles, including $95^{\circ} \mathrm{C}$ for 15 seconds, 30 seconds at $62^{\circ} \mathrm{C}$ and $72^{\circ} \mathrm{C}$ for 30 seconds. Standard curves were made for each primer pair to calculate amplification efficiency of the target genes and the endogenous control gene (EF0013). Differential expression was determined by calculating the change in threshold cycles for each gene with the $\Delta \Delta \mathrm{Ct}$-method, with RNA isolated from resistant mutants and wild type bacteria.

\section{DNA manipulations and sequencing}

Isolation of DNA from E. faecalis V583 and mutants was done using Advamax-beads (Advanced Genetic Technologies Corp.). PCR products were generated with Phusion DNA polymerase (Finnzymes). Other enzymes for DNA manipulation were from New England Biolabs. DNA fragments were purified by use of agarose gel electrophoresis and Qiaquick PCR purification columns (Qiagen). Plasmids were isolated using Qiagen miniprep columns. Standard procedures [32] were used for restriction cutting of DNA, ligation and cloning in $E$. coli. DNA was sequenced using the ABI Prism BigDye terminator sequencing ready reaction kit version 3.1 and analyzed with the ABI Prism 3100 genetic analyzer according to the supplier's procedures (Applied Biosystems).

\section{Results}

Isolation and characterization of bacteriocin resistant mutants

Four class IIa bacteriocin resistant mutants of E. faecalis V583 were obtained. Mutants MOP1 and MOP5 were isolated after exposure to two different concentrations of pediocin PA-1. A third spontaneous mutant (MOP2) was obtained by selecting colonies resistant to 2-DG. The MOP2 mutant was also resistant to pediocin (Table 2). Pediocin PA-1 resistant mutants were isolated at a frequency of $310^{-4}$, consistent with reported resistance frequency in Enterococcus and Listeria [6,7]. Previous studies have shown that pediocin resistance can be obtained by mutations in the mannose PTS operon, $m p t$ [33,34], therefore we constructed a resistant E. faecalis V583 (MOM1) disrupted in mptD. Mutants MOM1 and MOP5 were highly resistant to pediocin PA-1, while MOP1 and MOP2 were less resistant (Table 2). The pediocin resistance phenotype was stably maintained in all mutants in the absence of bacteriocin. All mutants were resistant to 2-DG (results not shown). In exponential phase up to an optical density of 0.2 the mutants grew with the same growth rate as the wild type, after which they grew slower but reached a somewhat higher final density than the wild type (Figure 1).

The mutant strains showed reduced glucose consumption during growth (Table 3). In addition, these mutants

Table 2 Sensitivity to pediocin PA-1 of strains used

\begin{tabular}{cc}
\hline Strain & MIC (BU/ml) \\
\hline V585 & 5 \\
\hline MOP1 & 160 \\
\hline MOP5 & $>21 \cdot 10^{6}$ \\
\hline MOP2 & 160 \\
\hline MOM1 & $>21 \cdot 10^{6}$ \\
\hline
\end{tabular}




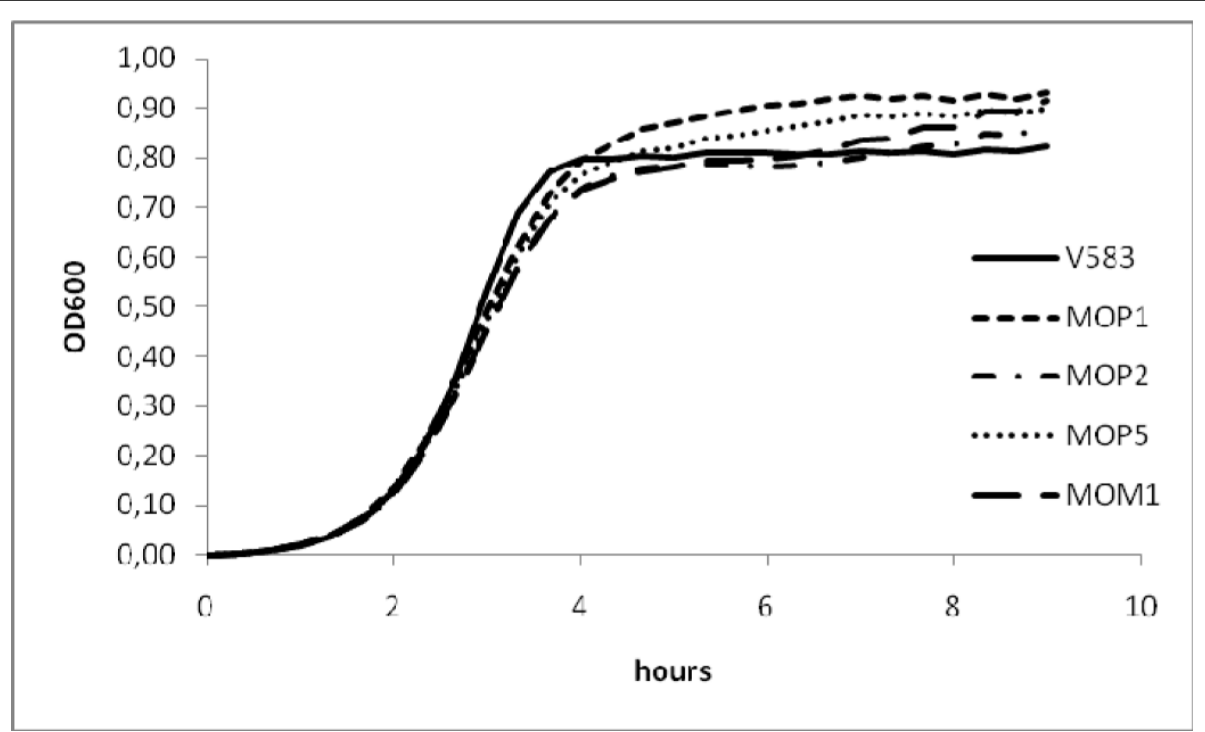

Figure 1 Growth curves of E. faecalis V583 and the resistant mutants in BHI. Each graph is based on average of ten parallels.

displayed changes in the metabolic profile by producing less lactate than the wild type, but more formate and ethanol.

Acid production was measured using washed cell suspensions with glucose or glycerol as substrates (Figure 2 ). The wild type produced acid from glucose more rapidly than the mutants. Acid production from glycerol was faster in the mutants. However, the rates were much lower than with glucose, and the wild type did not show detectable acid production.

\section{Transcriptional analyses of pediocin resistant strains of E. faecalis V583}

The transcriptional profiles of each of the four pediocin resistant mutants were compared to that of the parent strain using DNA microarrays of E. faecalis V583 under standard growth conditions. The microarray data used are the means of four independent biological replicates for the spontaneous mutants and four replicates for the $m p t D$-inactivated mutant. Significant differentially expressed genes in each of the individual mutants were identified using one-class analysis in the statistical software SAM [31]. The three spontaneous mutants showed large similarities in transcriptional responses, and by using the two-class module in SAM no significant difference between them could be identified. Furthermore, DNA sequencing showed no mutations in the $m p t$ operon in any of these mutants, but they all had the same transversion mutation in EF0018 resulting in amino acid substitution A356G in the transcription regulator MptR. This alanine is conserved among MptR homologs (results not shown). Consequently, to gain strength to the statistical analysis all the 12 microarrays representing the spontaneous mutants were treated as parallels of the same experiment and called MOP. In MOP 119 genes showed more than two-fold change in expression, and in MOM1 184 genes were differentially expressed. Most of the genes were upregulated; only 15 and 11 genes were downregulated in MOP and MOM1, respectively. These genes and their expression profiles are listed in Additional file 1. As shown in Additional file 1, MOP and MOM1 had very similar transcriptional

Table 3 Metabolites in supernatants of BHI-grown E. faecalis V583 and mutant strains

\begin{tabular}{lccccccc}
\hline & & \multicolumn{1}{c}{ Metabolites $(\mathbf{m M})$} & & & \\
\cline { 3 - 8 } Strain or genotype & OD600 $\mathbf{~ n m}$ & Glucose & Citrate & Lactate & Formate & Acetate & Ethanol \\
\hline V583 & 0.2 & 1.95 & 0.19 & 6.13 & 0.02 & 1.30 & 0.44 \\
MOM1 & 0.2 & 1.03 & 0.21 & 3.64 & 0 & 1.30 & 0.41 \\
MOP1 & 0.2 & 1.01 & 0.00 & 1.03 & 0.05 & 1.38 & 0.60 \\
V583 & 0.8 & 7.82 & 1.02 & 20.76 & 5.30 & 7.14 & 3.28 \\
MOM1 & 0.85 & 7.82 & 1.02 & 17.40 & 16.44 & 8.82 & 5.61 \\
MOP1 & 0.9 & 7.82 & 1.02 & 11.60 & 18.79 & 10.74 & 8.72 \\
\hline
\end{tabular}

The composition of the BHI growth medium was: glucose, $7.82 \mathrm{mM}$; citrate $1.02 \mathrm{mM}$; acetate $4.50 \mathrm{mM}$; formate $0.01 \mathrm{mM}$, and other substrates in low concentrations. 
A.

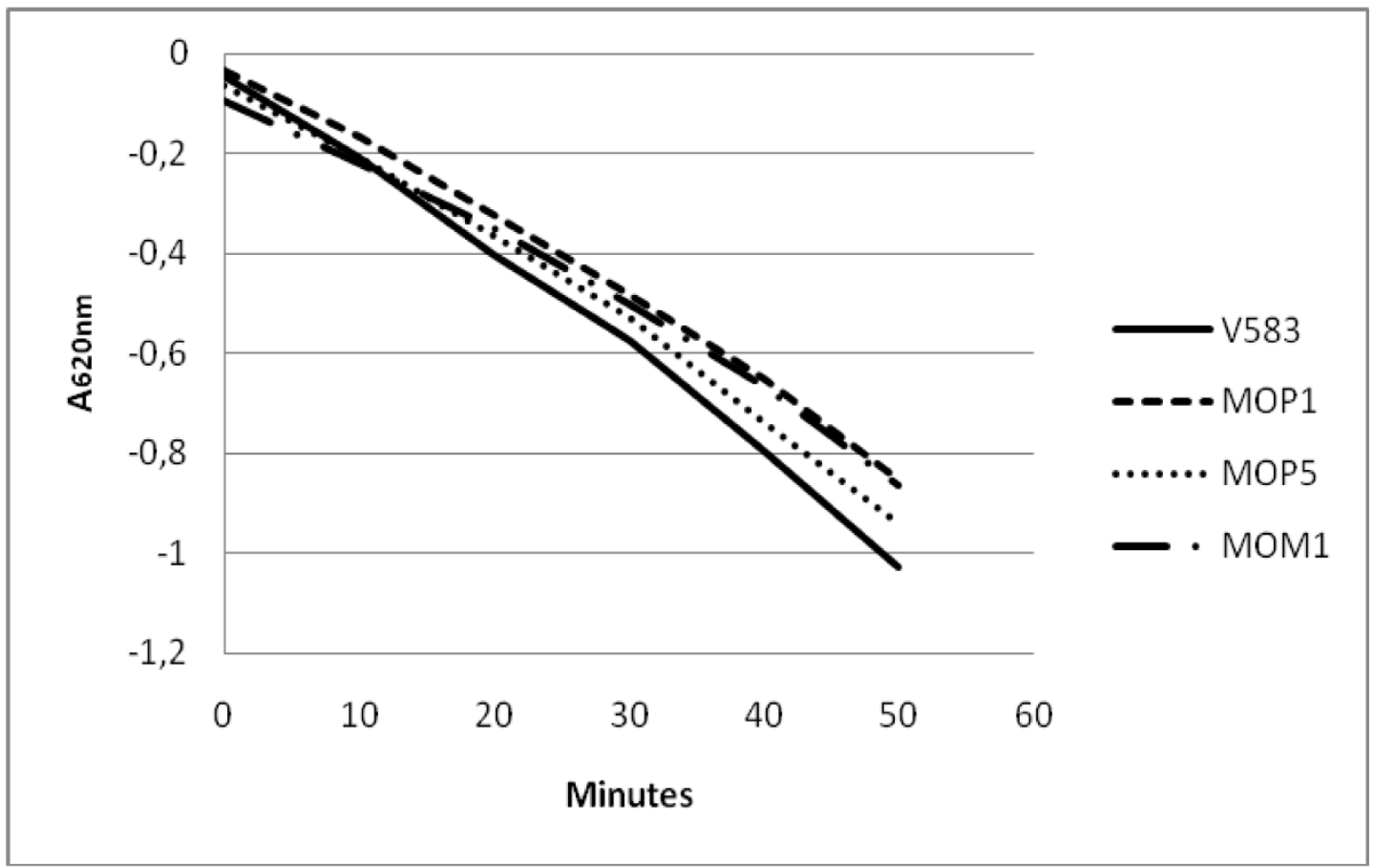

B.

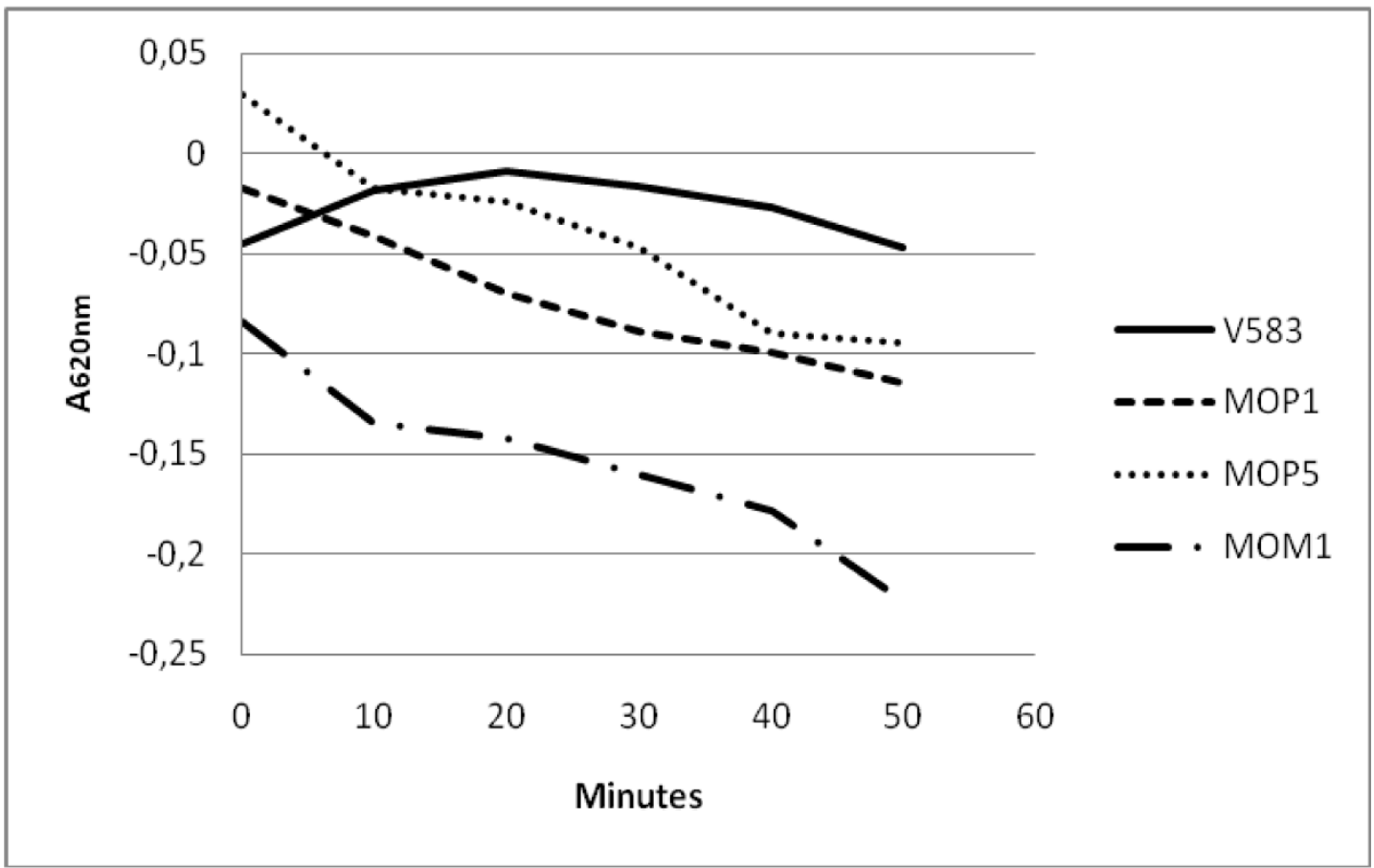

Figure 2 Acid production from glucose (A) and glycerol (B) by cell suspensions of $E$. faecalis V583 and resistant strains. Each graph is based on average of three parallels. 
profile, but we observed enhanced fold change ratio of nearly every gene in the mptD-inactivated mutant compared with the spontaneous mutants. Two-class analysis identified 24 genes with a significant difference in transcription between MOM1 and MOP, and 12 of them had more than two-fold change in expression in the $\Delta m p t D$ mutant only (Table 4).

The differentially expressed genes are distributed across the entire genome and the majority encodes proteins involved in energy metabolism, transport and binding, signal transduction, or of unknown functions (Figure 3). Validation of the differential expression of nine genes was performed using quantitative real-time PCR (qPCR). These genes represented different patterns of expression from various functional groups. As shown in Table 5, the results were in general in high concordance with the microarray results but the strongest responses were more pronounced with qPCR, demonstrating the wider dynamic range of response by this technique.

\section{Genes showing reduced expression in bacteriocin resistant mutants}

Only few genes were significantly downregulated in the resistant mutants. These genes encode proteins involved in transport, binding and energy metabolism. Most pronounced effects in transcription of the pediocin resistant mutants was the strong reduction in gene expression of the mannose PTS operon (EF0019-EF0022). This $m p t$ operon is $\sigma^{54}$-regulated [34], and has an unusual gene organization as it contains an additional gene encoding a distinct EIIB in front of the genes for the EIIAB, EIIC and EIID proteins and the last gene EF0024 (Figure 4). Despite the strong down-regulation, the signals were not completely abolished. Quantitative real-time PCR analyses confirmed reduced transcription of $m p t C$ representing the $m p t$ operon (Table 5). The downstream gene EF0024 was also downregulated indicating that it belongs to the $m p t$ operon. This gene, referred to as manO [35], encodes a protein highly conserved among strains of lactic acid bacteria, is part of the mannose

Table 4 Genes identified with significant different transcriptional profile between MOM1 and MOP mutants of E. faecalis

\begin{tabular}{|c|c|c|c|}
\hline ORF & $\log _{2}$ ratio MOP & $\log _{2}$ ratio MOM1 & Protein encoded by gene (Gene name) \\
\hline EF0071 & -0.37 & 0.77 & lipoprotein, putative \\
\hline EF0352 & -0.15 & -0.75 & hypothetical protein \\
\hline EF0751 & 0.63 & -0.51 & conserved hypothetical protein \\
\hline EF0754 & 0.25 & -0.68 & conserved hypothetical protein \\
\hline EF0755 & -0.03 & -1.35 & conserved hypothetical protein \\
\hline EF0900 & 0.19 & 2.00 & aldehyde-alcohol dehydrogenase (adhE) \\
\hline EF1036 & 0.49 & 2.76 & nucleoside diphosphate kinase \\
\hline EF1227 & -0.01 & 1.06 & conserved hypothetical protein \\
\hline EF1422 & 0.11 & 0.85 & transcriptional regulator, $\mathrm{Cro} / \mathrm{Cl}$ family \\
\hline EF1566 & -0.64 & 0.57 & 3-phosphoshikimate 1-carboxyvinyltransferase (aroA) \\
\hline EF1567 & -0.39 & 0.52 & shikimate kinase (aroK) \\
\hline EF1603 & -0.15 & 1.01 & sucrose-6-phosphate dehydrogenase (scrB-1) \\
\hline EF1619 & -0.33 & 2.31 & carbon dioxide concentrating mechanism protein $\mathrm{CcmL}$, putative \\
\hline EF1624 & -0.38 & 1.58 & aldehyde dehydrogenase, putative \\
\hline EF1627 & -0.36 & 2.79 & ethanolamine ammonia-lyase small subunit (eutC) \\
\hline EF1629 & -0.24 & 2.27 & ethanolamine ammonia-lyase large subunit (eutB) \\
\hline EF1732 & 0.37 & 2.01 & ABC transporter, ATP-binding/permease protein, MDR family \\
\hline EF1750 & -0.04 & 0.46 & endo/excinuclease amino terminal domain protein \\
\hline EF1760 & 0.11 & 0.48 & cell division $A B C$ transporter, permease protein Fts $X$, putative \\
\hline EF1769 & 0.01 & 1.45 & PTS system, IIB component, putative \\
\hline EF2216 & 0.07 & 0.80 & hypothetical protein \\
\hline EF2254 & -0.06 & -1.37 & hypothetical protein \\
\hline EF2887 & 0.26 & -0.40 & Not annotated \\
\hline EF3029 & 0.14 & 0.64 & PTS system, IID component \\
\hline EF3041 & 0.07 & -0.58 & pheromone binding protein \\
\hline
\end{tabular}

The genes were identified by two-class SAM analyzes and their corresponding expression levels are included. 


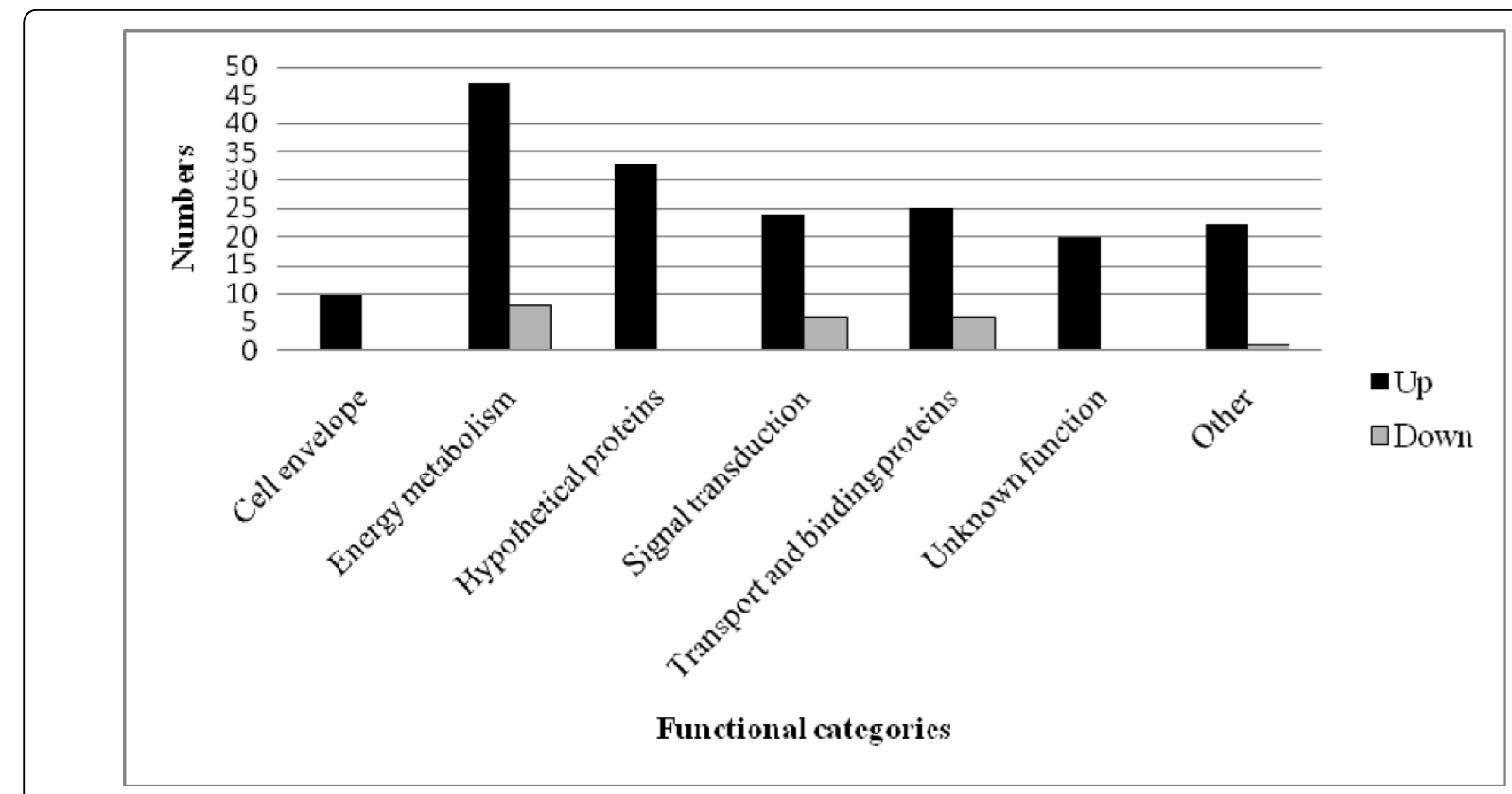

Figure 3 Numbers and functional categories of the 207 genes differentially expressed in resistant strains of $E$. faecalis V583.

PTS operon in L. monocytogenes and Lactobacillus casei $[36,37]$.

As expected, MOM1 showed reduced hybridization to the $m p t D$ probe, but the mutant also exhibited reduced expression of the upstream genes in the mpt operon indicating that MptD is involved in the regulation of its own synthesis. Strongly reduced gene expression of EF0082 encoding a major facilitator family transporter was detected in both the spontaneous mutants and in the $\Delta m p t D$ mutant. Interestingly, also the genes gap-2, $p g k$, triA, eno (EF1961-64), gpm (EF0195), pyk (EF1046) and ldh-1 (EF0255) encoding enzymes of glycolytic metabolism

Table 5 Gene expression analyzed by quantitative realtime PCR and microarray of mutant MOP1

\begin{tabular}{llcc}
\hline & & Microarray & Quantitative RT-PCR \\
\hline Gene ID & Gene & Log $_{\mathbf{2}}$ ratio & Log $_{\mathbf{2}}$ ratio \\
\hline EF0013 & dnaB & 0.02 & 0.04 \\
\hline EF0020 & mptAB & -2.80 & -2.07 \\
\hline EF0021 & mptC & -0.68 & -3.07 \\
\hline EF0022 & mptD & -1.70 & -2.48 \\
\hline EF0024 & manO & -0.59 & -3.29 \\
\hline EF0105 & argF-1 & 3.06 & 3.83 \\
\hline EF0106 & araC & 3.02 & 3.28 \\
\hline EF0633 & tyrS-1 & -0.82 & -1.46 \\
\hline EF1963 & pgk & -1.53 & -2.71 \\
\hline EF3320 & citE & 4.90 & 5.83 \\
\hline
\end{tabular}

Gene regulation values $\left(\log _{2}\right)$ are the average results of four biological replicates for microarray experiments and of two biological replicates for quantitative PT-PCR. were expressed to a lower extent in the resistant strains. Of the remaining genes for the complete pathway for glucose consumption, $f b a$ and $p f k$ showed 1.6-fold reduced expression (excluded by the 2-fold-change cut off in Additional file 1). Furthermore, the genes in the fructose operon encoding a transcription regulator, fructose-specific PTS IIABC and 1-phosphofructokinase (fruK-2), showed reduced transcription in all mutants.

Genes with enhanced expression in bacteriocin resistant mutants are involved in alternative pathways of energy metabolism

About $90 \%$ of the differentially expressed genes were upregulated in the mutants, and of them having an ascribed function most encode proteins involved in energy metabolism, transport, binding and signal transduction (see Additional file 1).

Since the $m p t$ operon is $\sigma^{54}$-regulated, we examined if other $\sigma^{54}$-controlled genes were affected in the mutants. By in silico analysis of the genome sequence of E. faecalis V583 using the sigma-54 promoter specific consensus sequence of $B$. subtilis YTGGCACNNNNNTTGCW [38], 10 putative $\sigma^{54}$-dependent promoters were identified. Four of them are preceded by a gene encoding a $\sigma^{54}$-dependent activator, and downstream genes encoding PTS enzyme II. Only the mpt operon showed reduced expression, while up-regulation only was observed for $m p h D$ localized downstream of EF1955 encoding a LevR-like $\sigma^{54}$-dependent activator. 


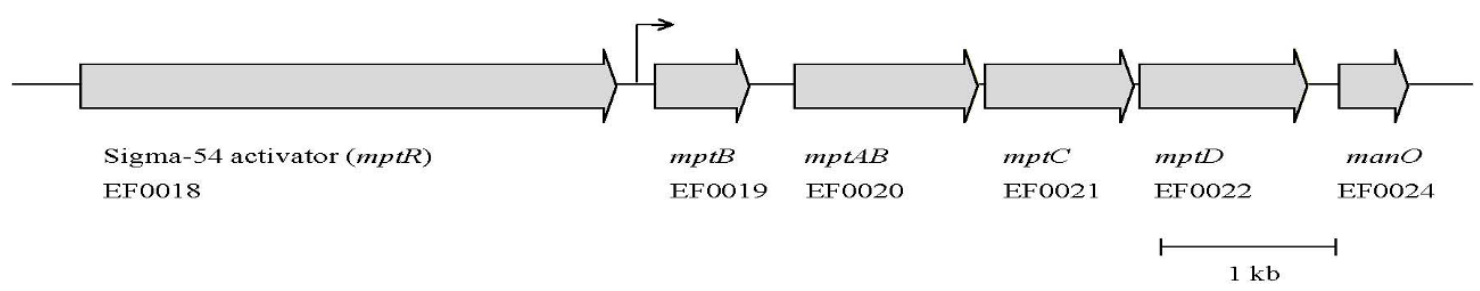

Figure 4 Genetic organization of the mannose PTS operon of $E$. faecalis V583 and the preceding $\sigma^{54}$-associated activator gene $m p t R$. The mpt operon contains the mpt genes, an additional gene encoding an EllB and the distal gene that resembles manO. The $\sigma^{54}$-promoter sequence is indicated by an arrow.

\section{Involvement of catabolite-responsive elements (cre)}

The large number of up-regulated catabolic genes in the mutants suggests the involvement of a global regulator. In Firmicutes carbon catabolite repression (CCR) is mediated via binding of the catabolite control protein $\mathrm{A}$ (CcpA) to operators known as catabolite-responsive elements cre [39]. By searching the E. faecalis V583 genome using the cre query consensus sequence WTGNAANCGNWNNCW developed for B. subtilis [40], we found 34 intergenic putative catabolite-responsive elements, and 21 of them were in the promoter regions of operons showing significant increased transcription in the mutants (see Additional file 1). Another 42 of the promoter regions of differentially expressed genes contained sequences with one mismatch to the $B$. subtilis cre-consensus. We propose that these sequences represent cre-sites of E. faecalis (see Additional file 2). Their sequences were aligned and had the consensus sequence WTGWAARCGYWWWCW. Many of the differentially expressed genes contained this sequence in their coding regions, and two were located in the intergenic regions downstream the down-regulated genes EF0635 and EF1046 (see Additional file 1). As shown in Additional file 1, a large majority of the differentially expressed genes are associated with putative cre-sites, and seven of them possibly regulate divergent expression. Many of the up-regulated genes located downstream of putative cre-sites encode enzymes involved in the use of alternative energy and carbon sources. Among them, genes encoding enzymes involved in citrate transport and catabolism (EF3314 to 3328) had the greatest increase in expression, up to sixty-fourfold in the mutants. A cre-site was found in the intergenic region between the two divergent cit operons. The arc operon, preceded by a cre-site encodes the energy yielding enzymes by arginine consumption, was also up-regulated in the mutants. Other substrates whose catabolic genes appear to be repressed via cre-sites in the wild type and not in the mutants were serine, galactose, lactose, glycerol and sucrose.

The transcription of several transcriptional regulators appeared to be regulated via cre-sites, suggesting involvement of CCR in regulatory cascades. None of the genes encoding proteins mediating CCR (hprK, ptsH and $\operatorname{ccp} A$ ) had significantly changed expression.

Ten of the genes showing enhanced expression encode proteins predicted to contribute to virulence [19]; proteins involved in chitin catabolism (EF0361 + 62), polysaccharide lyase (EF0818), serine protease and coccolysin (EF1817 + 18), secreted lipase (EF3060), two ABC transporters of iron and peptides (EF3082, EF3106), lipoprotein of YaeC family (EF3198), and cell surface anchor family protein (EF3314). All of them were associated with cre-sites and therefore under potential CCR regulation.

\section{Discussion}

We compared the transcriptomes of wild type E. faecalis V583 and stable pediocin PA-1 resistant mutants. The mutants were spontaneously resistant isolates, and since sensitivity to class IIa bacteriocins in E. faecalis is dependent on $\mathrm{mpt}$, we also constructed and studied an insertion inactivated $m p t D$ mutant. The transcriptomes were obtained from cells grown to early exponential growth phase in rich medium.

In $E$. faecalis the mpt operon is under transcriptional control from a promoter recognized by $\sigma^{54}$ and depending on the activator MptR, encoded by EF0018 [33,34]. The spontaneous bacteriocin resistant isolates contain a mutation in $m p t R$ causing down-regulation of the $m p t$ operon. Mutant MOP5, derived from MOP1, was resistant to higher bacteriocin concentrations than the other spontaneous mutants, but we could not identify sequence differences in $m p t R$ or the $m p t$ operon between these mutants, indicating that changes in other DNA sequences may also contribute to bacteriocin resistance in E. faecalis.

Our data confirm previous findings on the role of the mannose PTS in bacteriocin sensitivity, but the most striking results were the extensive changes of transcription among genes involved in carbohydrate metabolism, caused by inactivation of the mpt PTS. The mutants showed reduced glucose consumption, demonstrating the important role of Mpt in glucose metabolism in 
E. faecalis. Glucose consumption was not abolished, however, showing that the bacteria have alternative, less efficient glucose uptake systems, probably among the transport systems upregulated in the mutants. The presence of multiple glucose uptake systems is common in bacteria, and transporters additional to the mannose PTS were recently described in Lactococcus lactis and $L$. monocytogenes [41,42]. Impaired glucose uptake and metabolism affects the energy status of the cells, leading to changes in concentrations of glycolytic metabolites. Yebra et al [37] showed that disruption of the mannose PTS caused a slower glucose uptake and relief of glucose repression in L. casei.

The altered energy status is sensed by the HPr-kinase/ phosphorylase and implemented on the PTS phosphorcarrier protein HPr [13,43-45]. In cells with a high energy status HPr is phoshorylated at Ser-46 and can then form a complex with CcpA $[43,45]$. In CCR or CCA (carbon catabolite activation) the CcpA/HPr-Ser-P complex regulates transcription through binding to the cre-sites [46].

Most of the differential gene expression observed in our experiments could be ascribed to carbon catabolite regulation via $\mathrm{cre}$-sites. CCR in E. faecalis has been studied by others, but not by transcriptomic analysis. It has been reported that enzymes for degradation of citrate, arginine, serine, galactose and glycerol are under control of CCR in E. faecalis [47-50]. This is in agreement with our finding that these genes are up-regulated and associated with cre-sites. The metabolism of glycerol shows that our mutants were catabolic derepressed.

The consensus sequence of the extragenic putative cre-sites compiled in this study is WTGWAARCGYWWWC, very similar to what has been reported in B. subtilis [40]. Most of the operons affected contain upstream cre-sites, but in several cases the putative cresite is found within the open reading frames. Interestingly, three of the differentially expressed genes have the putative cre-site positioned in the intergenic region immediately downstream of the genes. Regulation of transcriptional initiation involving a 3'-cre located within the open reading frame but distantly separated from the promoter has been suggested to involve DNA looping [51]. To our knowledge, cres located downstream of the regulated gene have not been reported.

Another down-regulated gene with a putative cre-site in its promoter was EF0082, encoding a major facilitator family transporter. The gene has also been found to be positively regulated by a PrfA-like regulator, Ers, encoded by EF0074 [52].

Altogether, transcription involving about $90 \mathrm{cre}$-sites appeared to be affected in E. faecalis by disturbing its mannose PTS. About $65 \%$ of the putatively CCR regulated genes encode proteins involved in uptake and metabolism of alternative energy sources. It is noteworthy that a number of genes showing increased transcription in our mutants encode transcription regulators suggesting that regulatory cascades are involved. Among them were EF1025 and EF1026, encoding the homologs of CcpN and Yqfl which are involved in CcpA independent CCR in B. subtilis [53].

When phosphorylated at His-15 by phosphotransfer from phosphoenolpyruvate via enzyme I, HPr has other regulatory functions. HPr-His-P reaches high levels in cells with a low energy status in response to reduced levels of glycolytic intermediates and ATP, and increased level of Pi and PEP [12]. It can by phosphorylation regulate the activity of PTSs, enzymes such as DhaK and GlpK and transcriptional regulators [13,48,54,55].

Interestingly, not only the spontaneous mutants but also the mptD-inactivated mutant showed a strong reduced transcription of the $m p t$ operon. The decreased transcription was also seen in the genes upstream of the disrupted $m p t D$, suggesting that a functional PTS is necessary for transcription of the mpt operon. The $m p t$ regulator MptR contains two PTS regulatory domains (PRDs) flanking an EIIA domain like its homologs, ManR of Listeria innocua and the well studied LevR of B. subtilis $[13,56,57]$. Phosphorylation in EIIA of LevR mediated by HPr-His-P leads to activation of lev transcription, while phosphorylation of PRD-II at His-869 by the specific PTS EIIB ${ }^{\text {Lev }}$ negatively regulates transcription. Based on mutation analyses it was suggested that $m p t$ transcription in L. innocua is similarity regulated by phosphorylation of ManR, and that phosphorylation at both sites would also downregulate mpt transcription [58]. Such a model can be reconciled with our findings on mpt transcription regulation in E. faecalis, and in the mptD-inactivated mutant EIIAB ${ }^{\mathrm{Mpt}}$ will phosphorylate MptR (at PRD-II) and thereby negatively regulate transcription of its own operon. We cannot exclude that the weak $m p t$ signals of MOM1 are caused by altered mRNA stability. Reduced expression was also seen for EF0024 located downstream of $m p t D$, indicating it being a part of the $m p t$ operon. This gene is highly conserved downstream the mannose PTS genes in lactic acid bacteria, Listeria and Clostridium, and it is down-regulated in a $\sigma^{54}$ mutant of L. monocytogenes, implying that it is part of the mannose PTS operon also in this organism [36].

The $m p h$ operon is regulated by another $\sigma^{54}$-depending regulator, encoded by EF1955 [34], which has a domain architecture similar to MptR and LevR and the phosphorylatable histidines are conserved among the three regulators. The up-regulation of the $m p h$ operon seen in our mutants can probably be ascribed to activation of the regulator by phosphorylation of its EIIA $^{\mathrm{Mph}}$-domain (His-566) by HPr-His-P. Such activation would be prevented in the wild type growing on glucose [13]. 
HPr-His-P can control transcription dependent on regulators containing PTS domains and PRDs [13]. Two PRD containing antiterminator proteins were identified in the E. faecalis genome, and enhanced expressions was observed for one (EF1515), along with the downstream gene encoding an $\mathrm{N}$-acetylglucosamine-specific EIIABC, a multidomain PTS protein. Regulators of this BigGfamily cause release of termination structures in mRNA and enhanced transcription of downstream PTS genes when activated by HPr-His-P $[59,60]$, which can explain the increased gene expression in the mutants. In an analogous manner, the increased expression seen for the ascorbate-specific EIIB and EIIC genes are possibly caused by HPr-His-P mediated phosphorylation of the regulator encoded by the upstream EF2966. The EF2966 gene product contains PRDs and PTS domains and is probably a transcription regulator, but has erroneously been annotated as a BglG-type antiterminator although it lacks an RNA-binding domain [55].

Possibly, most or all the changes in gene expression in the mutants are caused by altered energy status of the cells, sensed by changes in metabolite concentrations. But not all the effects seen in our mutants could be directly ascribed to HPr phosphorylation. In E. faecalis fructose utilization is not under CCR [50,61], and no cre-site was detected in the fru promoter region of the downregulated fru operon (EF0717-19). This is in contrast to L. lactis where fructose utilization is regulated via CCR [62]. The fructose operon in L. lactis is also regulated by FruR and activation is dependent on fructose-1-phosphate [62]. The fru operon (EF0717-19) has a similar genetic organization in E. faecalis, including a fruR homolog and a putative FruR recognizing promoter which suggests that the fru operon is under repression of FruR in the mutants due to lowered intracellular levels of fructose-1-phosphate.

All the genes encoding enzymes leading from glucoses to lactic acid were down-regulated in the mutants. The $l d h-1$, encoding the major lactate dehydrogenase in E. faecalis [25], appears to be regulated by CCA, like in L. lactis [63]. Genes in the central glycolytic operon (gap-2, pgk, tpiA, eno) showed reduced expression probably as a consequence of low fructose-1,6-bis phosphate (FBP) concentration, and repression mediated by the central glycolytic gene repressor CggR encoded by the first gene in the operon, EF1965. A putative CggR operator sequence upstream of EF1965 was identified using the criteria of Doan \& Aymerich [64]. In B. subtilis, the repressor binds the operator localized upstream of $\operatorname{cggR}$ when not bound to FBP $[64,65]$.

The observed shift in metabolic profile toward more mixed acid fermentation reflects the transcriptional changes observed, but also the changes in concentration of central metabolic intermediates [66].
The spontaneous mutants MOP1 and MOP2 showed some Mpt activity, as substantiated by intermediate bacteriocin sensitivity. The deletion mutant could not have any Mpt activity and would probably have a lower energy status than the other strains. In agreement with this, we observed quantitative differences in responses between the spontaneous mutants and the constructed mutant. Generally, all transcriptional effects were stronger in the constructed mutant. In B. subtilis Singh and colleagues [67] reported that the strength of $\mathrm{cre}$-site dependent CCR is dependent only of the HPr-Ser-P levels in the cells, with involvement of different co-repressors as glucose-6$P$ and FBP [68]. We show that difference in strength of CCR is not only limited to $c r e$-site dependent CCR.

Abranches et al [69] studied the transcriptome of an EIIAB mannose-PTS mutant of $S$. mutans. A much lower number of genes were upregulated in that case, but largely the effects were similar to our results of $E$. faecalis. Like in the pediocin resistant $E$. faecalis, a significant number of genes encoding uptake systems and catabolic enzymes were up-regulated, demonstrating its central role in regulation of energy metabolism in these organisms. However, notable differences were also seen; PTS for trehalose (EF0958) and a gene for sodium-iron-translocating uptake (EF3324), both downregulated in the $S$. mutans mutant were up regulated in the E. faecalis mutants. Moreover, central glycolytic genes showed an opposite regulation in the two species. These differences could be a result of niche adaptation and reflect the difference in habitat of these human lactic acid bacteria. The fitness cost associated by a lack of $\mathrm{CCR}$ is a probable reason why mutants resistant to class IIa bacteriocins are rarely isolated from nature.

\section{Conclusion}

We have demonstrated global transcriptional effects in $E$. faecalis mutants resistant to class IIa bacteriocins, caused by changes in the mpt operon. The majority of the effects can be attributed to relief from glucose repression and lack of CCA. This mannose PTS is central in regulating carbon catabolite control in this organism. Our study is the first to characterize the cre-dependent and -independent responses in carbon catabolite control in enterococci.

\section{Additional material}

Additional file 1: Table A1: Transcriptional differences between the bacteriocin resistant mutants and the wild type. ${ }^{\text {TT}}$ The gene

expression ratios are shown as the log2 values of expression in the mutant samples, MOP and MOM1, over that in the wild type, of the differentially expressed genes. Gene expression ratio are indicated by 1 when the fold-change ration data are under 2 and/or the q-values are higher than $0 .{ }^{b}$ Gene included with special interest, when not meet the statistical thresholds. 'Putative cre-site adjacent gene is indicated with an arrow and illustrates gene(s) controlled by the same cre-site. The arrow is solid filled when the cre-site corresponds to the cre-consensus proposed 
by Miwa [40], and the arrow is not filled when it contains one mismatch. The cre-site position is either localized in the promoter ${ }^{\mathrm{a}}$, intragenic ${ }^{\mathrm{b}}$ or downstream of the gene (gradient filled arrow). ${ }^{\text {T}}$ The functional categories are: A. Amino acid biosynthesis, B. Biosynthesis of cofactors, prosthetic groups and carriers, C. Cell envelope, D. Cellular processes, E. Central intermediary metabolism, F. DNA metabolism, G. Energy metabolism, H. Hypothetical proteins, I. Protein fate and synthesis, J. Purines/pyrimidines/nucleosides/nucleotides, K. Regulatory functions, L. Signal transduction, M. Transcription, N. Transport and binding proteins, and $\mathrm{O}$. Unknown function.

Additional file 2: Table A2: Summary of the putative cre-sites of regulated genes in the mutant strains. Sequence and start position of the 63 putative promoter catabolite-responsive elements of the regulated genes in the pediocin PA-1 resistant mutants, MOM1 and MOP of $E$. faecalis $V 583$.

\section{Acknowledgements}

This work was funded by a grant from the Research Council of Norway. We acknowledge Zhian Salehian, Linda H. Godager and Kari R. Olsen for technical assistance.

\section{Author details}

Laboratory of Microbial Gene Technology and Food Microbiology, Department of Chemistry, Biotechnology and Food Science, Norwegian University of Life Sciences, N-1432 Ås, Norway. ${ }^{2}$ Tine SA, N-0051 Oslo, Norway.

\section{Authors' contributions}

MO participated in the design of the study, carried out the experimental work, image and statistical analyzes, analyzed and interpreted data, and wrote the manuscript. HH conceived the study, participated in the design of the study and data interpretation, and helped to write the manuscript. IFN conceived the study, participated in the design of the study and corrected the manuscript. All authors have read and approved the manuscript.

Received: 21 May 2010 Accepted: 25 August 2010

Published: 25 August 2010

\section{References}

1. Klaenhammer TR: Genetics of bacteriocins produced by lactic acid bacteria*. FEMS Microbiol Rev 1993, 12(1-3):39-85.

2. Nes IF, Diep DB, Holo H: Bacteriocin diversity in Streptococcus and Enterococcus. J Bacteriol 2007, 189(4):1189-1198.

3. Chikindas ML, Garcia-Garcera MJ, Driessen AJ, Ledeboer AM, Nissen-Meyer J, Nes IF, Abee T, Konings WN, Venema G: Pediocin PA-1, a bacteriocin from Pediococcus acidilactici PAC1.0, forms hydrophilic pores in the cytoplasmic membrane of target cells. Appl Environ Microbiol 1993, 59(11):3577-3584.

4. Drider D, Fimland G, Hechard Y, McMullen LM, Prevost H: The continuing story of class lla bacteriocins. Microbiol Mol Biol Rev 2006, 70(2):564-582.

5. Katla T, Naterstad K, Vancanneyt M, Swings J, Axelsson L: Differences in susceptibility of Listeria monocytogenes strains to Sakacin P, Sakacin A, Pediocin PA-1, and Nisin. Appl Environ Microbiol 2003, 69(8):4431-4437.

6. Casaus P, Nilsen T, Cintas LM, Nes IF, Hernandez PE, Holo H: Enterocin B, a new bacteriocin from Enterococcus faecium T136 which can act synergistically with enterocin A. Microbiology 1997, 143(7):2287-2294.

7. Rekhif N, Atrih A, Lefebvre G: Selection and properties of spontaneous mutants of Listeria monocytogenes ATCC-15313 resistant to different bacteriocin produced by lactic acid bacteria strains. Curr Microbiol 1994, 28(4):237-241.

8. Diep DB, Skaugen M, Salehian Z, Holo H, Nes IF: Common mechanisms of target cell recognition and immunity for class II bacteriocins. Proc Natl Acad Sci USA 2007, 104(7):2384-2389.

9. Gravesen $A$, Ramnath $M$, Rechinger KB, Andersen N, Jansch L, Hechard $Y$, Hastings JW, Knochel S: High-level resistance to class lla bacteriocins is associated with one general mechanism in Listeria monocytogenes. Microbiology 2002, 148:2361-2369.
10. Héchard Y, Sahl HG: Mode of action of modified and unmodified bacteriocins from Gram-positive bacteria. Biochimie 2002, 84(5-6):545-557.

11. Ramnath M, Beukes M, Tamura K, Hastings JW: Absence of a putative mannose-specific phosphotransferase system enzyme IIAB component in a leucocin A-resistant strain of Listeria monocytogenes, as shown by two-dimensional sodium dodecyl sulfate-polyacrylamide gel electrophoresis. Appl Environ Microbiol 2000, 66(7):3098-3101.

12. Postma PW, Lengeler JW, Jacobson GR: Phosphoenolpyruvate: carbohydrate phosphotransferase systems of bacteria. Microbiol Rev 1993, 57(3):543-594.

13. Deutscher J, Francke C, Postma PW: How phosphotransferase systemrelated protein phosphorylation regulates carbohydrate metabolism in bacteria. Microbiol Mol Biol Rev 2006, 70(4):939-1031.

14. Naghmouchi K, Kheadr E, Lacroix C, Fliss I: Class I/Class Ila bacteriocin cross-resistance phenomenon in Listeria monocytogenes. Food Microbiol 2007, 24(7-8):718-727.

15. Tessema GT, Moretro T, Kohler A, Axelsson L, Naterstad K: Complex phenotypic and genotypic responses of Listeria monocytogenes strains exposed to the class lla bacteriocin Sakacin P. Appl Environ Microbiol 2009, 75(22):6973-6980.

16. Vadyvaloo V, Arous S, Gravesen A, Hechard Y, Chauhan-Haubrock R, Hastings JW, Rautenbach M: Cell-surface alterations in class lla bacteriocin-resistant Listeria monocytogenes strains. Microbiology 2004, 150(9):3025-3033.

17. Vadyvaloo V, Hastings JW, van der Merwe MJ, Rautenbach M: Membranes of class lla bacteriocin-resistant Listeria monocytogenes cells contain increased levels of desaturated and short-acyl-chain phosphatidylglycerols. Appl Environ Microbiol 2002, 68(11):5223-5230.

18. Vadyvaloo V, Snoep JL, Hastings JW, Rautenbach M: Physiological implications of class lla bacteriocin resistance in Listeria monocytogenes strains. Microbiology 2004, 150(2):335-340.

19. Paulsen IT, Banerjei L, Myers GSA, Nelson KE, Seshadri R, Read TD, Fouts DE, Eisen JA, Gill SR, Heidelberg JF, et al: Role of mobile DNA in the evolution of vancomycin-resistant Enterococcus faecalis. Science 2003, 299(5615):2071-2074.

20. Sahm DF, Kissinger J, Gilmore MS, Murray PR, Mulder R, Solliday J, Clarke B: In vitro susceptibility studies of vancomycin-resistant Enterococcus faecalis. Antimicrob Agents Chemother 1989, 33(9):1588-1591.

21. Gonzalez CF, Kunka BS: Plasmid-associated bacteriocin production and sucrose fermentation in Pediococcus acidilactici. Appl Environ Microbiol 1987, 53(10):2534-2538.

22. Holo H, Nilssen O, Nes IF: Lactococcin A, a new bacteriocin from Lactococcus lactis subsp. cremoris: isolation and characterization of the protein and its gene. J Bacteriol 1991, 173(12):3879-3887.

23. Elliker PR, Anderson AW, Hannesson G: An agar culture medium for lactic acid Streptococci and Lactobacilli. J Dairy Sci 1956, 39(11):1611-1612.

24. Bond DR, Tsai BM, Russell JB: Physiological characterization of Streptococcus bovis mutants that can resist 2-deoxyglucose-induced lysis. Microbiology 1999, 145(10):2977-2985.

25. Jönsson M, Saleihan Z, Nes IF, Holo H: Construction and characterization of three lactate dehydrogenase-negative Enterococcus faecalis V583 mutants. Appl Environ Microbiol 2009, 75(14):4901-4903.

26. Holo H, Nes IF: High-frequency transformation, by electroporation, of Lactococcus lactis subsp. cremoris grown with glycine in osmotically stabilized media. Appl Environ Microbiol 1989, 55(12):3119-3123.

27. Marsili RT: Monitoring bacterial metabolites in cultured buttermilk by high performance liquid chromatography and headspace gas chromatography. J Chromogr Sci 1981, 19(9):451.

28. Narvhus JA, Thorvaldsen K, Abrahamsen RK: Quantitative determination of volatile compounds produced by Lactococcus ssp. using direct automatic headspace gas chromatography. XXII Int Dairy Congr: 1990; Montreal, Canada 1990, 522.

29. Aakra A, Vebø H, Snipen L, Hirt H, Aastveit A, Kapur V, Dunny G, Murray B, Nes IF: Transcriptional response of Enterococcus faecalis V583 to erythromycin. Antimicrob Agents Chemother 2005, 49(6):2246-2259.

30. Saal L, Troein C, Vallon-Christersson J, Gruvberger S, Borg A, Peterson C: BioArray Software Environment (BASE): a platform for comprehensive management and analysis of microarray data. Genome Biol 2002, 3(8): software0003.0001-software0003.0006 
31. Tusher VG, Tibshirani R, Chu G: Significance analysis of microarrays applied to the ionizing radiation response. Proc Natl Acad Sci USA 2001, 98(9):5116-5121.

32. Sambrook J, Russell DW: Molecular Cloning: A Laboratory Manual. Cold Spring Harbor, NY Cold Spring Harbor Laboratory Press, 32001.

33. Dalet $K$, Cenatiempo Y, Cossart P, Hechard Y: A sigma(54)-dependent PTS permease of the mannose family is responsible for sensitivity of Listeria monocytogenes to mesentericin Y105. Microbiology 2001, 147:3263-3269.

34. Héchard Y, Pelletier C, Cenatiempo Y, Frére J: Analysis of sigma(54)dependent genes in Enterococcus faecalis: a mannose PTS permease (EllMan) is involved in sensitivity to a bacteriocin, mesentericin Y105. Microbiology 2001, 147:1575-1580.

35. Lortie LA, Pelletier M, Vadeboncoeur C, Frenette M: The gene encoding $\| \mathrm{AB}_{\mathrm{L}}{ }^{\mathrm{Man}}$ in Streptococcus salivarius is part of a tetracistronic operon encoding a phosphoenolpyruvate: mannose/glucose phosphotransferase system. Microbiology 2000, 146:677-685.

36. Arous S, Buchrieser C, Folio P, Glaser P, Namane A, Hebraud M, Héchard Y: Global analysis of gene expression in an rpoN mutant of Listeria monocytogenes. Microbiology 2004, 150(5):1581-1590.

37. Yebra MJ, Monedero V, Zúñiga M, Deutscher J, Pérez-Martinez G: Molecular analysis of the glucose-specific phosphoenolpyruvate: sugar phosphotransferase system from Lactobacillus casei and its links with the control of sugar metabolism. Microbiology 2006, 152(1):95-104.

38. Barrios H, Valderrama B, Morett E: Compilation and analysis of sigma(54)dependent promoter sequences. Nucleic Acids Res 1999, 27(22):4305-4313.

39. Deutscher J: The mechanisms of carbon catabolite repression in bacteria. Curr Opin Microbiol 2008, 11(2):87-93.

40. Miwa Y, Nakata A, Ogiwara A, Yamamoto M, Fujita Y: Evaluation and characterization of catabolite-responsive elements (cre) of Bacillus subtilis. Nucleic Acids Res 2000, 28(5):1206-1210.

41. Castro R, Neves AR, Fonseca LL, Pool WA, Kok J, Kuipers OP, Santos H: Characterization of the individual glucose uptake systems of Lactococcus lactis: mannose-PTS, cellobiose-PTS and the novel GlcU permease. $\mathrm{Mol}$ Microbiol 2009, 71(3):795-806

42. Stoll R, Goebel W: The major PEP-phosphotransferase systems (PTSs) for glucose, mannose and cellobiose of Listeria monocytogenes, and their significance for extra- and intracellular growth. Microbiology 2010, 156(4):1069-1083.

43. Deutscher J, Reizer J, Fischer C, Galinier A, Saier MH, Steinmetz M: Loss of protein kinase-catalyzed phosphorylation of $\mathrm{HPr}$, a phosphocarrier protein of the phosphotransferase system, by mutation of the $\mathrm{pts} H$ gene confers catabolite repression resistance to several catabolic genes of Bacillus subtilis. J Bacteriol 1994, 176(11):3336-3344.

44. Deutscher J, Saier MHJ: ATP-dependent protein kinase-catalyzed phosphorylation of a seryl residue in $\mathrm{HPr}$, a phosphate carrier protein of the phosphotransferase system in Streptococcus pyogenes. Proc Natl Acad Sci USA 1983, 80(22):6790-6794.

45. Kravanja M, Engelmann R, Dossonnet V, Bluggel M, Meyer HE, Frank R, Galinier A, Deutscher J, Schnell N, Hengstenberg G: The hprK gene of Enterococcus faecalis encodes a novel bifunctional enzyme: the HPr kinase/phosphatase. Mol Microbiol 1999, 31(1):59-66.

46. Jones BE, Dossonnet V, Kuster E, Hillen W, Deutscher J, Klevit RE: Binding of the catabolite repressor protein CcpA to its DNA target is regulated by phosphorylation of its corepressor HPr. J Biol Chem 1997, 272(42):26530-26535.

47. Barcelona-Andres B, Marina A, Rubio V: Gene structure, organization, expression, and potential regulatory mechanisms of arginine catabolism in Enterococcus faecalis. J Bacteriol 2002, 184(22):6289-6300.

48. Deutscher J, Bauer B, Sauerwald H: Regulation of glycerol metabolism in Enterococcus faecalis by phosphoenolpyruvate-dependent phosphorylation of glycerol kinase catalyzed by enzyme I and $\mathrm{HPr}$ of the phosphotransferase system. J Bacteriol 1993, 175(12):3730-3733.

49. Leboeuf $C$, Leblanc $L$, Auffray $Y$, Hartke A: Characterization of the ccpA gene of Enterococcus faecalis: Identification of starvation-inducible proteins regulated by CcpA. J Bacteriol 2000, 182(20):5799-5806.

50. Rea MC, Cogan TM: Catabolite repression in Enterococcus faecalis. Syst Appl Microbiol 2003, 26(2):159-164.

51. Kim JH, Yang YK, Chambliss GH: Evidence that Bacillus catabolite control protein CcpA interacts with RNA polymerase to inhibit transcription. Mol Microbiol 2005, 56(1):155-162
52. Giard JC, Riboulet E, Verneuil N, Sanguinetti M, Auffray $Y$, Hartke A: Characterization of Ers, a PrfA-like regulator of Enterococcus faecalis. FEMS Imm Med Microbiol 2006, 46(3):410-418.

53. Servant $P, C o q D L$, Aymerich $S$ : $C c p N(Y q z B)$, a novel regulator for $C c p A$ independent catabolite repression of Bacillus subtilis gluconeogenic genes. Mol Microbiol 2005, 55(5):1435-1451.

54. Stülke J, Arnaud M, Rapoport G, Martin-Verstraete I: PRD - a protein domain involved in PTS-dependent induction and carbon catabolite repression of catabolic operons in bacteria. Mol Microbiol 1998, 28(5):865-874.

55. van Tilbeurgh $H$, Declerck N: Structural insights into the regulation of bacterial signalling proteins containing PRDs. Curr Opin Struct Biol 2001, 11(6):685-693.

56. Débarbouillé M, Martin-Verstraete I, Klier A, Rapoport G: The transcriptional regulator LevR of Bacillus subtilis has domains homologous to both sigma 54- and phosphotransferase system-dependent regulators. Proc Natl Acad Sci USA 1991, 88(6):2212-2216.

57. Martin-Verstraete I, Charrier V, Stülke J, Galinier A, Erni B, Rapoport G, Deutscher J: Antagonistic effects of dual PTS-catalysed phosphorylation on the Bacillus subtilis transcriptional activator LevR. Mol Microbiol 1998, 28(2):293-303.

58. Xue JF, Miller KW: Regulation of the mpt operon in Listeria innocua by the ManR protein. Appl Environ Microbiol 2007, 73(17):5648-5652.

59. Amster-Choder $\mathrm{O}$ : The $\mathrm{bg} /$ sensory system: a transmembrane signaling pathway controlling transcriptional antitermination. Curr Opin Microbiol 2005, 8(2):127-134

60. Schilling $\mathrm{O}$, Herzberg $\mathrm{C}$, Hertrich $\mathrm{T}$, Vorsmann $\mathrm{H}$, Jessen $\mathrm{D}$, Hübner $\mathrm{S}$, Titgemeyer $F$, Stülke J: Keeping signals straight in transcription regulation: specificity determinants for the interaction of a family of conserved bacterial RNA-protein couples. Nucl Acids Res 2006, 34(21):6102-6115.

61. Yun JS, Ryu HW: Lactic acid production and carbon catabolite repression from single and mixed sugars using Enterococcus faecalis RKY1. Proc Biochem 2001, 37(3):235-240.

62. Barriere C, Veiga-da-Cunha M, Pons N, Guedon E, van Hijum S, Kok J, Kuipers OP, Ehrlich DS, Renault P: Fructose utilization in Lactococcus lactis as a model for low-GC gram-positive bacteria: Its regulator, signal, and DNA-binding. J Bacteriol 2005, 187(11):3752-3761.

63. Luesink EJ, van Herpen R, Grossiord BP, Kuipers OP, de Vos WM: Transcriptional activation of the glycolytic las operon and catabolite repression of the gal operon in Lactococcus lactis are mediated by the catabolite control protein CcpA. Mol Microbiol 1998, 30(4):789-798.

64. Doan T, Aymerich S: Regulation of the central glycolytic genes in Bacillus subtilis: binding of the repressor CggR to its single DNA target sequence is modulated by fructose-1,6-bisphosphate. Mol Microbiol 2003, 47(6):1709-1721.

65. Ludwig H, Homuth G, Schmalisch M, Dyka FM, Hecker M, Stülke J: Transcription of glycolytic genes and operons in Bacillus subtilis: evidence for the presence of multiple levels of control of the gapA operon. Mol Microbiol 2001, 41(2):409-422

66. Cocaign-Bousquet M, Even S, Lindley ND, Loubiere P: Anaerobic sugar catabolism in Lactococcus lactis; genetic regulation and enzyme control over pathway flux. Appl Microbiol Biotechnol 2002, , 60: 24-32.

67. Singh KD, Schmalisch MH, Stülke J, Görke B: Carbon catabolite repression in Bacillus subtilis: Quantitative analysis of repression exerted by different carbon sources. J Bacteriol 2008, 190(21):7275-7284.

68. Schumacher MA, Seidel G, Hillen W, Brennan RG: Structural mechanism for the fine-tuning of $\mathrm{CcpA}$ function by the small molecule effectors glucose 6-phosphate and fructose 1,6-bisphosphate. J Mol Biol 2007, 368(4):1042-1050.

69. Abranches J, Candella MM, Wen ZT, Baker HV, Burne RA: Different roles of EllABMan and EllGlc in regulation of energy metabolism, biofilm development, and competence in Streptococcus mutans. J Bacteriol 2006, 188(11):3748-3756

doi:10.1186/1471-2180-10-224

Cite this article as: Opsata et al:: Class lla bacteriocin resistance in Enterococcus faecalis V583: The mannose PTS operon mediates global transcriptional responses. BMC Microbiology 2010 10:224. 